\title{
Respon jaringan periodontal terhadap penggunaan nikel kromium sebagai komponen gigitiruan cekat
}

\author{
Ardiansyah S. Pawinru,* Edy Machmud** \\ *Bagian Ilmu Teknologi Material Kedokteran Gigi \\ **Bagian Prostodonsia \\ Fakultas Kedokteran Gigi Universitas Hasanuddin \\ Makassar, Indonesia
}

\begin{abstract}
The use of fixed partial denture (FPD) nowdays has been very popular in our society. This is due to their smaller size, and more convenient to be used and fixed in the mouth. The choice of nickel chromium (NiCr) as the metal component of FPD is based on its character of corrosion proof, light, and hard. However, nickel contained can be allergic. Allergic reactions reported, vary from oedema of tongue and lip, and mouth lining until anaphylaxis. These reactions are related to the pattern and corrosion modes, followed by the release of metalic ions like nickel into the oral cavity. This depends not only on the composition of metal, but also the temperature and $\mathrm{pH}$ of the oral cavity. Some studies have reported the use of $\mathrm{NiCr}$ might cause inflammation reaction of periodontal tissue.
\end{abstract}

Key word: nickel chromium, allergic reaction, periodontal tissue

\begin{abstract}
ABSTRAK
Penggunaan gigitiruan cekat (GTC) dewasa ini di kalangan masyarakat sudah sangat populer. Hal ini dikarenakan GTC lebih kecil dan lebih nyaman digunakan serta terpasang secara cekat di dalam mulut. Pemilihan logam nikel kromium $(\mathrm{NiCr})$ sebagai bahan GTC didasarkan pada sifatnya yang tahan korosi, ringan, dan keras. Kandungan nikel pada bahan tersebut dapat bersifat sebagai alergen. Reaksi alergi yang dilaporkan bervariasi, yaitu edema lidah dan bibir, mouth lining, sampai dengan anafilaksis. Potensi logam sebagai alergen berhubungan dengan pola dan modus korosi, yang diikuti pelepasan ion-ion logam seperti nikel ke dalam rongga mulut. Hal ini tidak hanya tergantung pada komposisi logam, tetapi juga suhu dan $\mathrm{pH}$ di dalam rongga mulut. Beberapa laporan penelitian menjelaskan bahwa penggunaan bahan $\mathrm{NiCr}$ dapat menyebabkan reaksi inflamasi pada jaringan periodontal.
\end{abstract}

Kata kunci: nikel kromium, reaksi alergi, jaringan periodontal

Koresponden: Ardiansyah S. Pawinru, Bagian Ilmu Teknologi Material, Fakultas Kedokteran Gigi Universitas Hasanuddin, Jl. Perintis Kemerdekaan Km.10, Makassar, Indonesia. E-mail: pawinru_gigi@yahoo.com.

\section{PENDAHULUAN}

Beberapa penderita mungkin mengalami alergi terhadap logam sewaktu berkontak dengan kulit. Terdapat bukti bahwa bahan tahan korosi seperti baja nirkarat dan aloi cobalt chromium memproduksi sejumlah kecil produk korosi yang mungkin menyebabkan reaksi alergi. Kasus alergi menyangkut baja nirkarat dan aloi krom kobalt yang telah dilaporkan, menunjukkan bahwa unsur di dalam aloi seperti kobalt, nikel atau bahkan kromium bisa merupakan bahan penyebab sensitivitas. Ion logam yang terlepas juga 
merupakan komponen penyebab kulit menjadi sensitif. ${ }^{1,2}$

Beberapa penelitian menunjukkan adanya kenaikan kadar nikel dalam saliva dan serum secara bermakna setelah insersi gigitiruan cekat. Nikel merupakan logam yang sering menyebabkan dermatitis kontak dalam bidang kedokteran gigi dibandingkan dengan logam lain. Sekali hipersensitivitas terjadi, semua permukaan mukosa rongga mulut dapat terlibat. Sensitivitas meningkat dengan adanya iritasi mekanik, skin laceration atau luka pada mukosa mulut, yang semuanya dapat terjadi selama perawatan. Sampai saat ini sensitivitas penderita terhadap nikel melalui perawatan rutin telah banyak menjadi perhatian. Meskipun bahan baja nirkarat mempunyai kadar nikel yang relatif rendah, yaitu 6\%, bahan bebas nikel yang dapat menjadi alternatif pilihan adalah keramik (dari alumina polikristal, single crystal sapphire atau zirconia), polikarbonat (dari polimer plastik), bahan lapis emas dan titanium. ${ }^{1,3,4}$

Tampilan yang transparan dan translusen dari single crystal sapphire dan alumina polikristal membuat bahan ini secara estetik menyenangkan. Akan tetapi bahan ini bersifat abrasif apabila beradu dengan email. Estetika bahan polimer juga bagus, tetapi mempunyai masalah umum yaitu kurang kuat dan kaku. Selama mekanika pergeseran gigi, faktor daya tahan geser merupakan faktor yang penting, dan harus dikontrol agar aplikasi kekuatan ringan yang optimal dapat dilakukan. Daya tahan geser yang lebih tinggi memerlukan peningkatan besarnya kekuatan ortodontik untuk mengatasi frictional resistance agar didapatkan sisa kekuatan yang cukup untuk menggerakkan gigi secara optimal. Dari berbagai bahan yang diteliti, bracket baja nir karat lebih disukai karena nilai gaya geser yang rendah. Meskipun demikian, karena mengandung nikel, baja nirkarat dapat menyebabkan reaksi hipersensitivitas dan korosi pada lingkungan mulut. Selain itu dapat terjadi distorsi gambaran computed tomography (CT) dan magneted resonance imaging (MRI) karena adanya aloi baja nir karat. Untuk mengatasi hal ini dikembangkan bahan dari titanium. ${ }^{1,5,6}$

Berdasarkan bahasan ulasan di atas, pada makalah ini akan dibahas mengenai respon jaringan periodontal terhadap penggunaan bahan restorasi nickel chromium (NiCr).

\section{TINJAUAN PUSTAKA}

Nikel murni adalah suatu logam yang sangat keras. Sebagian dari logam seperti nikel dapat dicampur dengan besi, tembaga, kromium, dan seng. Campuran logam ini digunakan dalam pembuatan koin, perhiasan logam serta dalam industri pembuatan benda logam. Campuran nikel juga digunakan dalam pembuatan plat nikel, pewarna keramik, pembuatan baterei, dan sebagai katalisator untuk meningkatkan reaksi kimia. Nikel tidak memiliki bau khas atau pun berasa. ${ }^{7,8}$

Nikel adalah suatu unsur logam yang banyak digunakan sebagai unsur campuran logam yang dipakai dalam bidang kedokteran gigi. Meskipun nikel adalah salah satu penyebab alergi, tidak ada bukti yang menunjukkan bahwa alergi terjadi akibat kontak dengan peranti kedokteran gigi serta restorasi yang mengandung nikel. Reaksi hipersensitif mukosa terhadap nikel mungkin terjadi pada pasien yang sensitif akibat kontak mukosa dengan nikel atau logam lainnya, meskipun hal ini jarang terjadi. Bukti klinis dapat dilihat dari penggunaan alat-alat kedokteran gigi yang mempunyai komponen nikel, walaupun kecil, dapat mempengaruhi tingkat toleransi jaringan pada logam ini. ${ }^{9,10}$ 


\section{Sifat-sifat nikel}

Tujuan restorasi gigi bukan hanya menghilangkan dan mencegah berulangnya penyakit, tetapi juga untuk mengembalikan fungsinya. Untuk menggunakan suatu bahan, seorang dokter gigi harus mengetahui sifat-sifat bahan tersebut. Sifat penting yang harus dimiliki oleh bahan restorasi adalah harus mudah digunakan dan memiliki daya tahan lama, serta harus biokompatibel sehingga tidak menyebabkan reaksi pada jaringan. ${ }^{11,12}$

Sebagaimana kita ketahui, bahwa sifat yang ideal dari suatu bahan restorasi adalah tidak toksik dan tidak iritatif terhadap jaringan pulpa dan gingiva, serta tidak larut dan tidak mengalami korosi di dalam rongga mulut. Selain itu, suatu bahan restorasi juga harus memiliki kekuatan tensil yang cukup, sifat eksotermis yang rendah sehingga perubahan volume selama pengerasannya dapat diabaikan, koefisien muai dan difusi termik yang sama dengan email dan dentin, serta derajat keausan yang sama dengan email, dan kemampuan melindungi jaringan gigi sekitar dari kemungkinan terjadinya karies sekunder. ${ }^{11,12}$

Pada penggunaan komponen logam, seperti nikel, pada bidang kedokteran gigi harus diperhatikan sifat utama logam tersebut seperti biokompatibel dengan jaringan, ketahanan terhadap korosi, sifat mekanis serta kemudahan dalam aplikasinya. Komposisi kimia dan mikrostruktur nikel, seperti tingkat kekasaran permukaan, tingkat oksidasi yang tinggi, $\mathrm{pH}$ yang rendah mempunyai pengaruh yang besar terhadap ketahanan korosi dari nikel. ${ }^{7,13}$

\section{Keuntungan dan kerugian $\mathrm{NiCr}$}

Penggunaan $\mathrm{NiCr}$ sering menyebabkan reaksi alergi pada penggunanya. Hal ini diakibatkan oleh karena $\mathrm{NiCr}$ memiliki sifat korosi dan tingkat oksidasi yang tinggi, yang dapat dapat menyebabkan dermatitis pada penggunanya. Pada pasien yang menggunakan gigitiruan jembatan, secara signifikan terjadi peningkatan ion nikel pada cairan gingivanya. Sedangkan kelebihannya adalah merupakan komponen yang tahan karat, ringan, keras. ${ }^{13,14}$

\section{Komposisi NiCr}

Logam yang digunakan pada konstruksi GTC adalah aloi $\mathrm{NiCr}$, yang merupakan logam campur yang terdiri dari nikel, krom, silika, boron, karbon, mangan, dan besi. ${ }^{15}$

\section{Reaksi jaringan periodontal terhadap $\mathrm{NiCr}$}

Respon imun pada alergi pada mukosa rongga mulut melibatkan IgE, komplemen C3a, C4a dan C5a serta respon seluler. Kesehatan jaringan periodontal sangat erat kaitannya dengan restorasi gigi. Untuk itu kesehatan jaringan periodontal harus selalu diperhatikan karena restorasi dan gigi yang direstorasi dapat bertahan lama sedikit banyak tergantung pada kesehatan jaringan periodontalnya. ${ }^{2,14,16}$

Ada dua tahap terjadinya respon imun tipe IV yang menyebabkan timbulnya lesi dermatitis kontak, yaitu tahap sensitisasi dan tahap elisitasi.

Tahap sensitisasi atau induksi disebut juga tahap aferen. Pada tahap ini terjadi sensitisasi terhadap individu yang semula belum peka terhadap bahan kontaktan yang disebut alergen kontak atau pemeka. Hal tersebut terjadi bila hapten menempel pada kulit selama 18-24 jam, kemudian diproses dengan jalan pinositosis atau endositosis oleh sel langerhans epidermal (LE), untuk mengadakan ikatan kovalen dengan protein karier yang berada di epidermis menjadi komplek hapten protein. Protein ini terletak pada membran sel langerhans dan berhubungan 
dengan produk gen human leukocyte antigen$D R$ (HLA-DR) pada sel penyaji antigen (antigen presenting cell). Selanjutnya sel LE menuju duktus limfatikus, kemudian ke parakorteks limfonodus regional dan terjadilah proses penyajian antigen kepada molekul CD4+ (cluster of differentiation 4+) dan molekul CD3. CD4+ berfungsi sebagai pengenal komplek HLA-DR dari sel langerhans, sedangkan molekul CD3 yang berkaitan dengan protein heterodimerik $\mathrm{Ti}$ (CD3-Ti) merupakan pengenal antigen yang lebih spesifik, misalnya untuk ion nikel atau ion kromium saja. Keduanya terdapat pada permukaan sel T. Pada saat tersebut telah terjadi pengenalan antigen (antigen recognition). Selanjutnya sel langerhans dirangsang untuk mengeluarkan interleukin-1 (IL1) yang akan merangsang sel $T$ untuk mengeluarkan IL-2. Kemudian IL-2 akan mengakibatkan proliferasi sel $\mathrm{T}$ sehingga terbentuk primed memory $T$ cells, yang akan bersirkulasi ke seluruh tubuh meninggalkan limfonodi dan akan memasuki tahap elisitasi bila berkontak lagi dengan alergen yang sama. Proses ini pada manusia berlangsung selama 14 sampai 21 hari, dan belum terdapat ruam pada kulit. Pada saat itu individu tersebut telah tersensitisasi, yang berarti mempunyai resiko untuk mengalami dermatitis kontak alergik. $^{15,17}$

Tahap elisitasi, atau tahap eferen, terjadi apabila terjadi kontak kedua dari antigen yang sama dan sel yang telah tersensitisasi yang telah tersedia di dalam kompartemen dermis. Sel langerhans akan mensekresi IL-1 yang akan merangsang sel T untuk mensekresi IL-2. Selanjutnya IL-2 akan merangsang interferon gamma (INF- $\gamma$ ). IL-1 dan INF- $\gamma$ akan merangsang keratinosit memproduksi intercellular adhesion molecule-1 (ICAM-1) yang langsung beraksi dengan limfosit $\mathrm{T}$ dan lekosit, serta sekresi eikosanoid. Eikosanoid akan mengaktifkan sel mast dan makrofag untuk melepaskan histamin sehingga terjadi vasodilatasi dan permeabilitas meningkat. Akibatnya timbul berbagai macam kelainan kulit seperti eritema, edema dan vesikula yang akan tampak sebagai dermatitis. Proses peredaan atau penyusutan peradangan terjadi melalui beberapa mekanisme yaitu proses skuamasi, degradasi antigen oleh enzim dan sel, kerusakan sel langerhans dan sel keratinosit serta pelepasan prostaglandin E-1dan 2 (PGE-1,2) oleh sel makrofag akibat stimulasi INF$\gamma$. PGE-1,2 berfungsi menekan produksi IL-2R sel $\mathrm{T}$ serta mencegah kontak sel $\mathrm{T}$ dengan keratisonit. Selain itu sel mast dan basofil juga ikut berperan dengan memperlambat puncak degranulasi setelah 48 jam terpapar antigen, diduga histamin berefek merangsang molekul CD8 (+) yang bersifat sitotoksik. Dengan beberapa mekanisme lain, seperti sel B dan sel T terhadap antigen spesifik, dan akhirnya menekan atau meredakan peradangan. $^{13,15}$

\section{PEMBAHASAN}

Berbagai macam logam campuran telah digunakan pada pembuatan GTC. Evaluasi reaksi dari setiap logam dan sistem campuran logam yang berbeda cukup sulit dilakukan, tidak hanya secara teknis, tetapi juga secara biologi dan klinis. Hal tersebut karena data yang tersedia sangat terbatas. Logam campur yang digunakan pada gigitiruan harus sangat diperhatikan komposisinya karena beberapa diantaranya merupakan unsur yang berpotensi beracun dan alergen, seperti nikel, kobalt, timah, kadmium dan berilium. Logamlogam tersebut telah diklaim dapat menyebabkan peradangan pada gingiva dan jaringan periodontal. ${ }^{4,18}$

Desain dan preparasi gigi untuk restorasi logam/porselen ataupun akrilik ditentukan oleh 
lima prinsip. Pertama, adalah pemeliharaan jaringan gigi. Disamping untuk menggantikan jaringan gigi yang telah diasah, suatu restorasi juga harus dapat dipertahankan. Meskipun demikian, permukaan jaringan gigi yang sehat tidak harus dihilangkan untuk mendapatkan kemudahan dan efesiensi dalam membuat restorasi. Kedua, retensi dan resistensi. Dalam praktek, retensi dan resistensi berhubungan erat dan sulit dibedakan. Retensi adalah kemampuan preparasi untuk menghalangi lepasnya restorasi melalui arah insersi dalam keadaan lapisan semen mendapat tegangan dan geseran. Resistensi sebaliknya adalah kemampuan preparasi untuk mencegah keluarnya restorasi oleh gaya yang arahnya ke apikal, miring atau horisontal. Selanjutnya prinsip ketiga, ketahanan struktur restorasi, harus cukup kuat untuk mencegah lapisan semen di bawahnya agar tidak patah. Oleh karena itu jaringan gigi yang dihilangkan harus cukup, sehingga terdapat jarak untuk membentuk kontur restorasi yang normal. Jika restorasi dibuat dengan kontur normal pada preparasi dengan pengurangan aksial yang tidak adekuat, maka dinding restorasi akan tipis dan mudah terjadi distorsi. Kurangnya celah pada daerah aksial menyebabkan tekniker sulit membuat pola malam, memendam dan menuang tanpa terjadi distorsi. Biasanya sebagai kompensasi, tekniker akan membuat dinding overcontour. Cara ini akan menimbulkan masalah pada jaringan periodontium. Prinsip berikutnya adalah integritas marginal. Ada tiga syarat untuk mendapatkan tepi restorasi yang baik, yakni harus serapat mungkin dengan tepi akhir preparasi, cukup kuat menahan tekanan kunyah, dan jika memungkinkan harus ditempatkan pada daerah yang mudah diperiksa oleh dokter gigi dan mudah dibersihkan oleh penderita. Restorasi cekat dapat bertahan lama dalam rongga mulut jika tepinya beradaptasi baik dengan cavosurvace finish line. Konfigurasi dari garis akhir preparasi menentukan bentuk dan ketebalan dari logam serta kecekatan tepi restorasi. ${ }^{12}$ Prinsip terakhir adalah pemeliharaan jaringan periodontium. Dahulu garis akhir gingival preparasi ditempatkan pada subgingiva. Namun, saat ini beberapa peneliti menyatakan bahwa tepi restorasi subgingiva menjadi penyebab radang gingiva yang dapat menjalar menjadi periodontitis. $^{19,20}$ Posisi subgingiva memang memberi estetik yang baik terutama untuk gigi anterior bila dibandingkan dengan tepi restorasi supragingiva, tetapi tepi restorasi yang berada pada marginal gingiva atau supragingiva, radang gingiva jarang terjadi dan lebih mudah dilakukan pencetakan, sehingga restorasi pada bagian tersebut lebih baik. $^{10,21}$ Berdasarkan hasil penelitian yang menunjukkan besarnya resiko terjadi radang gingiva pada tepi restorasi subgingiva, maka posisi akhiran restorasi ini tidak digunakan lagi. Suatu tepi restorasi sedapat mungkin di tempatkan supragingiva. Kemungkinan nampaknya tepi restorasi harus dijelaskan kepada penderita disertai alasan-alasan pembuatannya, sebelum preparasi dilakukan. Pada keadaan-keadaan tertentu tepi restorasi dapat ditempatkan subgingiva, misalnya adanya karies, perluasan restorasi sebelumnya, estetik, fraktur gigi pada daerah subgingiva dan sensitivitas akar gigi. $^{22}$

Logam berat tidak dapat dimetabolisme di dalam tubuh sehingga tetap berada dalam tubuh serta menyebabkan efek toksik dengan cara bergabung dengan suatu atau beberapa gugus ligan yang esensial bagi fungsi fisiologis normal. Ligan adalah suatu molekul yang mengikat molekul lain yang umumnya lebih besar. Ligan memberi atau menerima elektron untuk membentuk ikatan kovalen, biasanya dengan logam. Antagonis logam berat, yaitu suatu kelator 
(chelating agent) khusus dirancang untuk berkompetisi dengan ligan terhadap logam berat, sehingga meningkatkan ekskresi logam dan mencegah atau menghilangkan efek toksiknya. ${ }^{23}$

Efektivitas suatu kelator untuk pengobatan keracunan logam berat tergantung dari beberapa faktor, yaitu afinitas relatif kelator terhadap logam berat dan logam esensial di dalam tubuh, distribusi kelator dan logam di dalam tubuh, dan kemampuan kelator untuk mengeluarkan logam dari dalam tubuh. Suatu kelator yang ideal sebaiknya memiliki sifat larut dalam air, resisten terhadap biotransformasi, mampu mencapai tempat penyimpanan logam, kelator yang terbentuk mudah diekskresi, dan harus aktif pada pH cairan tubuh. ${ }^{23}$

\section{SIMPULAN}

Kajian ini mengkonfirmasi bahwa pemilihan $\mathrm{NiCr}$ sebagai bahan gigitiruan cekat memiliki potensi untuk terjadinya reaksi alergi. Hal ini ditandai dengan terjadinya peningkatan ion nikel pada cairan gingival pasien, sehingga dokter gigi perlu memilih logam campur yang mempunyai pelepasan unsur-unsur yang paling rendah. Tujuan ini dapat tercapai dengan menggunakan logam mulia ataupun campuran logam mulia. Dibutuhkan riset lebih lanjut di dalam bidang ini, pada periode waktu yang panjang, untuk menilai kinerja klinis dari tuangan logam campur untuk restorasi cekat, serta pengaruhnya pada kesehatan gingiva.

\section{DAFTAR PUSTAKA}

1. Goenharto S, Sjafei A. Breket titanium. Dent J [serial online] 2005; [cited 2007, December 10] 2: 11-6. Available from: http:// www.journal.unair.ac.id/login/jurnal/filer/.

2. Prymak O, Bogdanski D, Koller $\mathrm{M}$. Morphological characterization and in vitro biocompatibility of a porous nickel-titanium alloy. [serial online] Available from: http://www.biorthex.com/pdf/Morphological \%20Micro\%20CT\%202005.pdf.www.elsevier .com/locate/ biomaterials. Institute for Inorganic Chemistry, University of DuisburgEssen, Germany. Available online 26 April 2005

3. Goenharto S, Sjafei A. Breket titanium. Dent J [serial online] 2005 [cited 2007 November 10]; 38: 5-9. Available from: http://www.journal.unair.ac.id/login/jurnal/file $\mathrm{r} /$.

4. Ciszewski A, Baraniak M. Corrosion investigations of some dental alloys in selected solutions. Magdalena UrbanekBrychczynska1 [serial online] 2005 [cited 2006 March 29]. Available from: http:// www.epadental.org/Epa.doc. Collegium Stomatologicum of Poznan University of Medical Sciences.

5. Santulli GA, Bethesda. Fixed prosthodontics review diagnosis and treatment planning concepts. Available from: http://www.bethesda.med.navy.mil/careers $\% 5$ Cpostgraduate_dental_school\%5Ccomprehens ive_dentistry\%5Cstudy_guides $\% 5$ Cspecialty_ reviews\%5Cpros_fixed\%5Cpros,\%20fixed.do c. Naval Postgraduate School. Available online 1 April 2007.

6. Baldwin PD, Pender N. Last effect on tooth movement of force delivery from nickeltitanium archwires. Eur J Orthod 1999; 2(6): 15-20.

7. Rahilly G, Price N. Current products and practice nickel allergy and orthodontics. J Orthod, British Orthodontic Society 2003; 30 (2): 171-4.

8. Donald M, Belles. SYLLABUS. Available from: http://www.db.uth.tmc.edu/studentacad/ 
Syllabi/2006/fall/DDS/3rd_Year/DENF\%203

901\%20Clinical\%20Prosthodontics.pdf.

Clinical Prosthodontics. 2006, Diakses tanggal 19 Januari 2007

9. Shenoy VK, Rodrigues S. Iatrogenic dentistry and the periodontium. A Department of Prosthodontics, Manipal College of Dental Sciences, Mangalore - 575 001, India journal by Medknow, Journal of Indian Prosthodontic. India vidsks@rediffmail.com.2005. Avalaible online 19 Mei 2006

10. Ramzy M.I., Gomaa H.E., Mostafa M. I, Zaki B. M., Management of Aggressive Periodontitis Using Ozonized Water http://www.mjnrc.com/vol4no1art16.pdf , diakses tanggal 3 Juni 2007

11. Peters, J. Strub R, Auschill T. Fracture resistance of three-unit posterior zirconium dioxide fixed partial dentures. An in vitro study. J Prosthet Dent 2006; 3; 16-20.

12. Hegeds L. Daróczi K, Beke D.L., Comparative Microstructural Study of the Diffusion Zone between NiCr Alloy and Different Dental Ceramics.www.hegedus@fogaszat.dote.hu. $J$ Dent Res 81(5): 334-337, 2002. Diakses tanggal 20 Mei 2006

13. Berenguer G, Forrest A, Horning M.G, Herbert J Towle, Karpinia Katherine, Localized Periodontitis as a Long-Term Effect of Oral Piercing: A Case Report. www.osap.org Compendium 2006 Department of Periodontology College of Dentistry University of Florida Health Science Center Gainesville, Florida. 2006 diakses tanggal 28 Juli 2007.

14. Geurtsen W. Biocompatibility of dental casting alloys. Department of Conservative Dentistry and Periodontology, Medical University Hannover, Germany; International and American Associations for Dental Research 2002; 3 (7): 30-6.

15. Trihapsoro I. Dermatitis kontak alergik pada pasien di Rumah Sakit Umum Pusat Haji Adam Malik Medan Sumatera Utara. Available from: http://library.usu.ac.id/ modules.php. FK USU. 2003. Diakses tanggal 18 Februari 2007.

16. Roeslan B. Imunologi oral. Jakarta: Balai Penerbit Fakultas Kedokteran Universitas Indonesia; 2002. hal. 70-90.

17. Gottehrer NR. Biocompatibilty implications of full-coverage crown restorations. Available from: http://www.captek.com/library/publish/ perspectives.pdf. 2005. Diakses tanggal 19 September 2006.

18. Nabavi M. Chronic idiopathic urticaria and refractory dermatitis in a case of vitamin b12 deficiency. Available from: http://www.journalagent.com/TJH-52724.

Saeman Medical University, Iran. Diakses tanggal 23 Agustus 2007

19. Ozden AN, Haghighat N. Al-Hashimi I. Preliminary evaluation of salivary pellicle on nickel-chromium alloy in vivo. Quintessence Int 2002; 5: 14-20.

20. Failures related to crowns and fixed partial dentures fabricated in a Nigerian dental school. J Contemp Dent Pract [serial online] 2005 [cited 2006 January 28]; 6 (4) Available from: http://www.thejcdp.com/issue024/ oginni/oginni.pdf.

21. Direct and indirect restorative materials. J Am Dent Assoc 2003; 134: 463-72.

22. Suzely ASM, Nemre AS, Orlando S, Lívia GZ, Márcio RCB. Association between dental prosthesis and periodontal disease in a rural Brazilian community. Braz J Oral Sci [serial online] 2006 [cited 2007 October 5]; 5: 19. 
Available from: http://libdigi.unicamp.br/ document/?view=19478.

23. Syarif A. Farmakologi dan terapi. Edisi ke-4.
Jakarta: Bagian Farmakologi Fakultas

Kedokteran Universitas Indonesia; 2001. hal. 112-30. 